DEMOGRAPHIC RESEARCH

VOLUME 33, ARTICLE 33, PAGES 951-984

PUBLISHED 5 NOVEMBER 2015

http://www.demographic-research.org/Volumes/Vol33/33/

DOI: 10.4054/DemRes.2015.33.33

Research Article

\title{
Measuring intergenerational financial support: Analysis of two cross-national surveys
}

\section{Tom Emery}

\section{Stipica Mudrazija}

(c) 2015 Tom Emery \& Stipica Mudrazija.

This open-access work is published under the terms of the Creative Commons Attribution NonCommercial License 2.0 Germany, which permits use, reproduction \& distribution in any medium for non-commercial purposes, provided the original author(s) and source are given credit.

See http://creativecommons.org/licenses/by-nc/2.0/de/ 


\section{Table of Contents}

1 Introduction 952

$2 \quad$ Background 953

$2.1 \quad$ Intergenerational transfers 953

2.2 Methodological literature 954

2.2.1 Prompts 954

2.2.2 Reference periods

2.2.3 Anchors 956

$\begin{array}{lll}2.3 & \text { Research question } & 957\end{array}$

3 Method 959

$\begin{array}{lll}3.1 & \text { Data } & 959\end{array}$

$\begin{array}{lll}3.1 .1 & \text { SHARE } & 959\end{array}$

$\begin{array}{lll}3.1 .2 & \text { GGP } & 961\end{array}$

3.2 Hypotheses 962

$4 \quad$ Results $\quad 965$

4.1 Prompts 965

$\begin{array}{lll}4.2 & \text { Reference period } & 968\end{array}$

$\begin{array}{lll}4.3 & \text { Anchors } & 972\end{array}$

5 Discussion 973

$6 \quad$ Acknowledgements 976

$\begin{array}{ll}\text { References } & 977\end{array}$

$\begin{array}{ll}\text { Appendix } & 980\end{array}$ 


\title{
Measuring intergenerational financial support: Analysis of two cross-national surveys
}

\author{
Tom Emery ${ }^{1}$ \\ Stipica Mudrazija ${ }^{2}$
}

\begin{abstract}

\section{BACKGROUND}

The last decade has seen considerable research into intergenerational financial transfers in Europe. This research has produced significant insights into the nature, causes, and consequences of such transfers, as well as evidence of cross-national variation. Yet the findings of this research field are almost exclusively based on data from the Survey of Health, Ageing, and Retirement in Europe (SHARE). The dependency on SHARE data and this specific methodological approach may limit the inferences made by researchers examining intergenerational transfers in Europe.
\end{abstract}

\section{OBJECTIVE}

This paper aims to explore whether instruments designed to measure intergenerational financial transfers are sensitive to various methodological parameters. Specifically, whether the prompts, reference period, and respondent identity affect the number and size of transfers that are reported.

\section{METHODS}

To achieve this we compare data from SHARE and the Generations and Gender Programme (GGP) using Propensity Score Matching to identify which survey reports the most transfers and whether these differences are stable across sub-groups. We also utilise specific features of SHARE and the GGP to examine whether variations in the reference period or asking the transfer giver or receiver affects the level of behaviour reported.

\section{RESULTS}

The results show that the instruments are highly sensitive to changes in wording, the reference period, and the identity of the respondent. This suggests that existing findings in the literature may be sensitive to the specific methodology used by SHARE.

\footnotetext{
${ }^{1}$ NIDI \& Erasmus University Rotterdam, the Netherlands. E-Mail: emery@nidi.nl.

${ }^{2}$ Urban Institute, Washington, D.C., U.S.A.
} 


\section{CONCLUSIONS}

Whilst SHARE is an excellent data source, we would encourage studies of intergenerational transfers to validate their findings with multiple data sources.

\section{Introduction}

The process of societal ageing raises many questions about the relationship between generations. With an increasing number of older persons relative to younger persons, it should be expected that intergenerational relationships are changing in their nature and form, and this is reflected by the rich literature that examines this topic. However, whilst substantive research questions are of importance, the ability to answer them is dependent upon data that accurately measures various aspects and dimensions of intergenerational relationships, exchange, and solidarity. This paper explores one such dimension, intergenerational financial transfers, and examines the existing instruments designed to measure this phenomenon in two social surveys: the Generations and Gender Programme (GGP) and the Survey of Health Ageing and Retirement in Europe (SHARE). From this evaluation, broader lessons for those studying intergenerational relations are drawn.

By considering the conceptualization, instrument design, and sampling unit associated with intergenerational financial transfers, this paper shows that there are significant differences in the way the GGP and SHARE conceptualize and measure intergenerational financial transfers. For example, the questions regarding financial transfers in SHARE and the GGP use different prompts, reference periods, and anchors, and these result in very different transfer levels being reported across countries. The extent to which these different conceptualizations of intergenerational financial transfers fit into theories of intergenerational relationships is therefore of considerable importance when making substantive conclusions about the scope and nature of intergenerational financial transfers. By examining the differences between the SHARE and the GGP, it is shown that the existing instruments capture different behaviours.

These differences have substantive implications for the study of intergenerational relationships and this paper argues that the analysis of intergenerational relationships is susceptible to methodological issues and impediments that need to be addressed by studies in the field. The conclusion details the potential consequences of these limitations and how they might be better addressed in the future by social surveys such as SHARE and the related family of surveys such as the GGP and household panel studies. The findings of this paper suggest that whilst the existing surveys are excellent, 
substantive research should avoid being overly dependent on a single survey or data source.

\section{Background}

\subsection{Intergenerational transfers}

There has been significant research into intergenerational financial transfers in Europe over the past decade as part of a broader interest in intergenerational exchange. Much of the existing literature on intergenerational financial transfers from parents to their adult children has come to the same conclusion: parents are a non-negligible source of financial support for young adults (Kohli 1999; Attias-Donfut, Ogg, and Wolff 2005). Subsequent research has elaborated on this and shown that transfer behaviour is highly dependent on the circumstances of the parent and the child (Albertini, Kohli, and Vogel 2007; Schenk, Dykstra, and Maas 2010). This approach looked to enrich previous analyses by taking into consideration the specific circumstances of parent and child as well as the cultural and institutional context in which the relationship existed (Szydlik 2008).

The interplay of parent and child characteristics has led to a considerable acceleration of our understanding of intergenerational exchange and this line of investigation has dominated the most recent transfer literature. Research has shown that transfer behaviour is associated with a diverse range of factors such as socio-economic background (Albertini and Radl 2012), family size and birth order (Emery 2013), and the child's decision to leave home (Albertini and Kohli 2012). This suggests that financial transfers are highly context-dependent and part of a more complex matrix of intergenerational exchange.

Recent research has focused on the role of financial transfers within this wider matrix of exchange to identify the broader significance of financial exchange between generations. This research has shown that transfers and other forms of intergenerational exchange such as cohabitation are interrelated and thus require specific empirical techniques to disentangle them. For example, transfers can be given in exchange for caring for elderly relatives (Leopold and Raab 2011). Yet the relationship between transfers and other forms of exchange has been shown to be complex, sometimes acting as a substitute and sometimes as a complement to other forms of exchange (Brandt, Haberkern, and Szydlik 2009). Furthermore, they also reflect and interact in a myriad of ways with the policy environment in which they are found (Brandt and Deindl 2013; Mudrazija 2014). 
In the past ten years this literature has therefore evolved from basic descriptions of transfers into a sophisticated understanding of how transfers interrelate with other forms of intergenerational exchange and the policy environment. However, all of this research is based on SHARE data, which acted as a catalyst for the development of this field of research. This raises the question of whether intergenerational transfers have become too dependent on a single data source and whether the aforementioned findings would hold with alternative data sources and methodologies.

A small number of non-SHARE studies have been conducted on individual countries in Europe. For example, Lennartson (2010) used data from Sweden to show that children 'in need' were not always more likely to receive financial support from their parents and the situation was far more dependent on the financial situation of the parents. Similarly, Leopold and Schneider (2010) found that whilst the receipt of financial transfers was highly correlated with specific family events such as marriage and divorce, no effect could be found regarding childbirth. This analysis was based on data from the German Socio-Economic Panel (SOEP) and, like the analysis from Sweden, was based on a sample of recipients rather than givers. To the best of the authors' knowledge these are the only two European studies of financial transfers that focus exclusively on the recipient perspective.

\subsection{Methodological literature}

The dependence of the existing literature upon data from SHARE may be problematic if the methodology used within SHARE affects the reported level of transfer behaviour. Whilst the module on financial transfers in SHARE is well designed, survey methodologists caution against drawing inferences from a single source or method, as it is then impossible to disentangle measurement error and sampling bias particular to the survey from the actual behaviour of the population. The phrase used by Rooney, Steinberg, and Schervish (2004) to describe this is "methodology is destiny". In the existing literature we have identified three methodological issues that might be influencing survey instruments regarding financial transfers.

\subsubsection{Prompts}

Prompts refer to the precise wording of questions within surveys as well as interviewer instructions or examples that are relayed to the respondent. They are designed to clarify what the question is trying to capture and to avoid any potential ambiguity and subsequent measurement error. Rooney, Steinberg, and Schervish (2004) showed in 
their study of volunteering in the United States that the form of prompts included within the question wording significantly affected the likelihood of reporting volunteer activity. Yet they are clear in their conclusion that this does not necessarily mean that prompts are desirable or undesirable, as it is possible that they could be either stimulating false recall or failing to effectively prompt for behaviour that has occurred. It does, however, show that the level of transfer behaviour is highly dependent on the prompts included within the question. Schaeffer and Presser (2003) argue that the issue of prompts is one of translation in which the interviewer is attempting to translate the concept targeted by the survey to the respondent. With financial transfers this can be difficult, given that the term itself is one widely used in academic research but not in day-to-day parlance.

This may have significant consequences for research in which the function and nature of the transfer is prominent. For example, Leopold and Raab's (2011) work on exchange and care-giving mostly refers to transfers as potentially part of a wide intergenerational exchange with younger generations, a process in which small but regular exchanges may well be prominent. By contrast, Albertini and Radl (2012) consider the transmission of social status, which puts greater emphasis on large transfers made at key times in the recipient's life. Both these studies found evidence to support their theories, but may have been able to go further if there had been a clearer understanding of what the SHARE measure included and excluded or if alternative sources using different operationalisations had been available. Currently, a single measure within SHARE is being used to measure what may well be conceptually different forms of financial transfer.

Schaeffer and Presser (2003) suggest that prompts to clarify the concept are incorporated as follow-up questions or as a tick list, allowing for transfer dimensions to be recorded and a clear understanding of the concept to be communicated. Both SHARE and the GGP have such follow-up questions regarding the recipient of a financial transfer and SHARE includes prompts on motivation. However these questions are only asked in the event that a respondent says "Yes" to the initial question of whether they made a transfer. Both the GGP and SHARE are therefore very reliant on prompts included within the initial question. However, to understand the impact of these prompts on responses it is necessary to conduct an analysis of multiple methodologies.

\subsubsection{Reference periods}

Reference periods for questions are also an area where methodological effects can be observed. It might be assumed that reference periods can be corrected post hoc if it is 
assumed that the recall of reporting transfer behaviour is not affected by the length of reference period. To do so, responses could be weighted by the reference period to which they refer to reflect differing exposure periods. However, it is possible that longer reference periods lead to a failure to recall certain events (Schwarz and Oyserman 2001). Furthermore, a shift in reference period has been shown to affect the respondents' understanding of the concept being referred to. In research conducted by Igou, Bless, and Schwarz (2002) for example, it was shown that when a reference period was longer, respondents interpreted it as pertaining to less frequent and more extreme forms of behaviour. This would suggest that a respondent understands what is meant by a financial transfer differently when asked about the last three years than when asked about the last four weeks.

In SHARE Wave 2, reference periods are defined as the time since Wave 1, and thus there is variation in the reference periods. Given that fieldwork practices and timing vary by country, this raises questions about the suitability of SHARE Wave 2 data for comparative research (Brandt and Deindl 2013). Furthermore, it raises questions about the comparability of these transfer instruments with Wave 1 of SHARE as well as with other social surveys that measure intergenerational transfers, such as the GGP.

\subsubsection{Anchors}

A further issue in the study of intergenerational relationships is the use of ego-centric network measures to describe intergenerational relationships and the anchoring of responses to one side of the relationship. This approach relies on one person reporting on their social networks, often using name-generator techniques to distinguish between different dyads within the network. In this approach the responses are always given as relative to the respondent (i.e., 'John is my brother' rather than 'John is my father's son' or 'John and I are brothers'). This approach is commonly adopted in survey research, given that it is difficult to survey whole networks due to the lack of an appropriate sampling frame and the compound effects of non-response rates (Kalmijn and Liefbroer 2010). However, ego-centric models can be problematic if their ego-centric nature is not incorporated in the analytical technique applied (Marsden, 2011). Existing research has suggested that givers of support underreport compared to recipients of support, suggesting a modesty effect (Mandemakers and Dykstra 2008), and that substantive conclusions can shift depending on the anchor used within analysis (Hagestad 2006)

In existing research using SHARE data, great care has been taken to avoid such errors and not to make general inferences about intergenerational relations or their impact on recipients of transfers. However, there is literature that assesses transfer from 
a recipient's perspective, and it remains unclear how this work is empirically linked to the literature on the donor perspective, given the use of ego-centric approaches in the measurement of transfers. That is to say, to what extent can studies using a recipient perspective, such as Leopold and Schneider (2010) and Lennartson (2010), be said to draw from the same operationalization as studies based on SHARE data?

When drawing inferences from such data, it has been stressed that a total network approach should not be assumed (Handcock and Gile 2010). A total network approach in which the entire network is captured would allow for researchers to make inferences about the recipient node of financial transfers, for example, or would enable researchers to infer about relationships more generally. In the existing literature it is common for an assessment of intergenerational transfers to be made in such terms (Kohli 1999; AttiasDonfut, Ogg, and Wolff 2005). Yet this is inappropriate given the sampling bias and measurement error incurred from taking an ego-centric approach to the study of intergenerational relationships (Hagestad 2006). Sampling bias occurs if the aim is actually to try to sample intergenerational dyads or relationships rather than members of one generation or another. If we collect this information from a sample of parents it omits some children, and vice versa. The resulting analysis is therefore not representative of relationships but of a particular side of those relationships. Measurement error can occur because the responses are filtered through the perspective of only one member of the relationship rather than of both or by using an objective measure.

Given that financial transfers are an abstract concept that exists within a complex network of intergenerational relationships, it is important to carefully examine the role of these methodological designs in the responses given by survey respondents. This is especially true in the literature on financial transfers, where the majority of studies have come from a single data source and methodological approach. In this instance, a specific trait of the SHARE data could determine the direction of an entire literature on intergenerational transfers in Europe, making the SHARE methodology its destiny.

\subsection{Research question}

Given the potential overdependence of intergenerational transfer research in Europe on SHARE, this paper aims to examine the extent to which differences in transfer behaviour between SHARE and the GGP are attributable to methodological differences. As a result, this paper sets out to examine the following question, which has been developed in response to the existing literature on intergenerational financial transfers: to what extent do different conceptualizations and methodologies used in the 
measurement of intergenerational financial transfers in SHARE and the GGP affect the estimates of the prevalence of parent-child transfers?

This question is persistently asked within the study of intergenerational financial transfers given the levels of ambiguity that exist. Despite continued attempts to clarify and firmly establish what should and what should not be considered as a transfer, there are a number of areas that remain ambiguous (McDaniel 1997). For example, do existing measures include all forms of financial transfer such as the transfer of ownership in property, shares, or other financial assets? Given the range and complexity of financial products currently on offer to consumers, intergenerational transfer research may not be measuring the full extent of financial support offered by older generations. SHARE itself has attempted to circumvent this through the use of prompts, which will be discussed in greater detail in the data and methods section. Yet these prompts only go some way to addressing the level of complexity involved in some financial arrangements. Similarly, it might be that other methodological aspects, such as the length of the reference period or identity of the respondent as a giver or receiver, affect the types of transfer that are recorded.

Concerns about how comprehensive the measure is that is included in the SHARE data relate to a persistently observed yet rarely discussed problem when it comes to the financial support given by parents to adult children. This is the observation that financial transfers are not as common as many theories of social mobility and family sociology have suggested (Cox and Jimenez 1992). Using SHARE data, it is persistently found that around $20 \%-25 \%$ of those over age 50 make a financial transfer to at least one of their adult children. This falls much further when the minimum cut-off point is increased beyond $€ 250$ per annum. According to the data from Wave 4 of SHARE, just $7.2 \%$ of the over-50s have ever made a transfer of $€ 5,000$ or more in their lifetime. Despite the small and infrequent nature of these transfers, research has consistently shown that they are associated with social mobility and exhibit a clear class gradient (Kohli 1999; Albertini and Radl 2012). This creates a paradox in intergenerational research in which the general behaviour is associated with important social outcome variables but the amounts described within the data do not correspond with the functions they are thought to play. For example, receiving a financial transfer may be associated with an increased likelihood of being a homeowner, but the financial transfers described are rarely large enough to be decisive in the purchase of a home.

Such concerns are also to be felt in other areas of intergenerational transfer research such as exchange and solidarity or life-course approaches. In SHARE waves 1 and 2 , only $13.8 \%$ of transfers were over $€ 1,000$ in value, meaning that just $2 \%-3 \%$ of potential recipients received a transfer of over $€ 1,000$. These are, therefore, predominantly relatively small amounts and yet they are often identified as part of an exchange for intensive care and support (Attias-Donfut, Ogg, and Wolff 2005) or key 
factors in enabling key life events such as marriage and the birth of grandchildren (Leopold and Schneider 2010).

The association between transfers and a variety of social outcomes and dynamics found by the existing literature could suggest that the transfers that are measured are hiding a much broader package of financial and material transfers. That is to say that these theories may be valid but they are supported by empirical evidence in spite of potentially poor measurement of the financial transfers that actually occur. For example, looking at the impact of transfers on social mobility may show an association between social mobility and transfers because the types of transfers that are captured by the survey instrument are highly correlated with those transfers that are not captured (Albertini and Radl 2012). Yet improving the measurement of financial transfers could reveal more complex patterns and processes involved in intergenerational financial exchange, as researchers would be able to more accurately measure the specific types of support that lead to improved chances of social mobility. In order to achieve this, it is necessary to consider what the existing instruments used by social surveys measure, and how they might be improved.

\section{Method}

\subsection{Data}

\subsubsection{SHARE}

To answer the research question, this paper uses data from SHARE and GGP, which both include instruments to measure intergenerational transfers, but using different methodologies. The majority of research on intergenerational transfers in Europe has been based on SHARE data, particularly from waves 1 and 2. SHARE is a crossnational, longitudinal survey of the over-50s (http://www.share-project.org/). For a detailed assessment of the methodology and fieldwork practices within SHARE please consult Alcser et al. (2005) or Table A1 in the Appendix, which provides an overview of the surveys. Waves 1 and 2 were conducted in 2004 and 2006. Wave 1 was conducted in 12 countries and Wave 2 was conducted in 14 countries. These waves are used instead of Waves 3 and 4 as they closely correspond with the fieldwork time for the GGP. Within SHARE, financial transfers are measured by a series of questions. The first of these asks individuals:

"Now please think of the time since the last interview. Not counting any shared housing or shared food, have you or your partner given 
any financial or material gift or support to any person inside or outside this household amounting to €250 or more?” (FT001 - By financial gift we mean giving money, or covering specific types of costs such as those for medical care or insurance, schooling, down payment for a home. Do not include loans or donations to charities (Survey of Health, Ageing \& Retirement in Europe 2011).)

One thing to note is that the question varies depending on whether the respondent took part in a previous round of SHARE. A new respondent was asked if s/he had given any financial or material gift in the last 12 months. Given that all respondents in the Czech Republic and Poland in Wave 2 were new respondents, in these countries we can expect the levels of transfers to be marginally lower, given that the reference period is 12 months rather than the approximate 30 months between waves that existing SHARE respondents would be asked to refer to. Indeed, there is considerable variation among those respondents who were participating in their second wave, with around $20 \%$ being interviewed within two years of their first interview and around $20 \%$ being interviewed after 30 months had passed. To circumvent this, only respondents who were completing their first SHARE interview were used in the comparisons with the GGP. However, we also use individuals' second interview in certain parts of the analysis to examine the consequences of this variable's reference period.

If the respondent answers yes to the initial question, it starts a loop sequence which looks at each payment in turn. The first of these questions identifies the person receiving the transfer:

“To whom did you or your partner provide such financial assistance or gift?”

The responses are recorded with children identified by a ranking system specified by the parent in the section on children within the survey. Next, the respondent is asked to specify an amount:

"About how much did you or your partner give to this person altogether in the time since the last interview?" (Add single values to arrive at a total amount in Euros. (Survey of Health, Ageing \& Retirement in Europe 2011).)

The loop will only be executed three times. This means that if a respondent made more than three transfers, the smallest transfers will not be included in the dataset. Only $4.23 \%$ of respondents made at least three transfers (to anybody, not just children). This is compared to $12.69 \%$ who made at least two transfers and $28.64 \%$ who made at least 
one. Therefore, some censoring of transfer behaviour does exist but the affects of such censoring are anticipated to be very small and priority is given to larger transfers.

\subsubsection{GGP}

The Generations and Gender Programme is a cross-national, longitudinal survey that has now been conducted in 19 countries (http://www.ggp-i.org/). The data used here is from Wave 1, which was primarily conducted between 2004-2006 ${ }^{3}$. An overview of the data quality and methodological procedures for the GGP can be found in Fokkema et al. (2015). For some of the analysis, the GGP will be compared with data from SHARE on a country-by-country basis, and therefore only countries that fielded both the GGP and SHARE will be included within these parts of the analysis. This is the case for five countries: Belgium, Czech Republic, France, Germany, and Poland. One considerable difference in the GGP compared to SHARE is that the sample is representative of the population aged 18-79, which allows a broader perspective on intergenerational transfers and the comparison of giving and receiving. When the GGP is directly compared with SHARE we limit the sample to 50-79-year-olds for both surveys so that they are comparable. However, in certain parts of the analysis the full sample is used to examine if the identity of the respondent as giver or recipient of transfers affects the measurement of transfers.

The instruments regarding intergenerational transfers in the GGP are somewhat similar to those in SHARE in that they also employ a loop system to assess individual transfers. First, respondents are asked:

"During the last 12 months, have you or your partner/spouse given for one time, occasionally, or regularly money, assets, or goods of substantive value to a person outside the household? Please think also about land and property you or your partner/spouse transferred during this time." 4

If respondents answer yes they are put into a question loop that allows them to give details of up to five transfers. Unfortunately, questions regarding transfer amounts and motivations contained a number of missing values and so were not usable in this particular analysis. By analysing these two data sources it is possible to examine the impact of some conceptual and methodological differences on estimates of transfer behaviour in Europe. This will not enable a full and comprehensive analysis of all

${ }^{3}$ The exception to this is Poland (2011).

${ }^{4}$ Country-specific wording is included in the Appendix. 
possible approaches to measurement but will enable some insight into how susceptible the estimates of transfer behaviour are to conceptual and methodological differences. A more comprehensive study could incorporate a full qualitative assessment of intergenerational financial transfers that examined the conceptual validity of the existing questions within comparative surveys. This, however, lies outside the scope of this research project, as the present aim is to examine the divergence between two preexisting data sources and the extent to which the conclusions of existing research might be affected by the conceptualisation and methodology followed by SHARE.

\subsection{Hypotheses}

As part of the comparison between the SHARE and the GGP data, four key hypotheses have been drawn that examine the role of wording, reference period, and respondent identity (giving vs. receiving) on the measurement of transfers. It should be stressed that it is not necessarily desirable that the two surveys measure the exact same concept, but it is informative to examine the extent to which different approaches produce different responses. Firstly, the question wording is considered by comparing SHARE and GGP. Given that the question in the GGP appears to be more open-ended and provides prompts for various types of transfer, it could be expected that the instrument in the GGP would record higher levels of transfer behaviour in the previous twelve months. Specifically, the prompts for land and property that are contained within the question text could lead to an increase in the reporting of large transfers of wealth. There is also reference in the question to "money, assets, or goods of substantive value", which could also act as prompts to respondents.

By contrast, the SHARE question starts by asking respondents to exclude transfers regarding shared housing and food, and then goes on to refer only to a "financial or material gift or support”. Within the interviewer instructions there are guidelines stating what should and should not be included, but this depends on a respondent asking for clarification. Finally, SHARE also includes a floor for transfer size. Conceptually this is very sensible, in that it reduces the recording of very small transfers such as birthday presents or token amounts. Nevertheless, it does suggest that SHARE uses a somewhat narrower definition of financial transfers than the GGP. Yet there is also reason to believe that the SHARE data may provide higher levels of transfer behaviour, especially given that SHARE references a specific amount of money and contains other questions in the survey that refer to other types of transfer such as inheritance. There are therefore reasons to believe that SHARE may report more transfers than the GGP. Given this ambiguity our first hypothesis is: 
H1: The percentage of transfers in SHARE will be different from in the GGP for a comparable sample of 50-79-year-olds.

This hypothesis merely states that we expect the recorded levels of transfer behaviour to differ between the surveys. The only thing we can say with any degree of confidence about the two surveys is that the conceptualizations of the financial transfer questions are different, and that the percentage of transfers recorded in the two surveys is, therefore, likely to be different. However, it might be possible to explore the differences further. Given that the GGP prompts for transfers of financial assets, property, and land, this might suggest that the difference between the GGP and SHARE would be particularly large for financially comfortable respondents. Because those with higher wealth and socio-economic status are probably more likely to make substantial transfers, the gap between the GGP and SHARE should be highest for those of higher socio-economic status. This is because those who make large transfers are more likely to report doing so when prompted by the GGP question rather than by the SHARE question. The converse could be argued however, because those of low socio-economic status maybe more likely to make very small transfers below the €250 floor that exists in SHARE. However, whilst this will be considered during the analysis, the predominant distinction between the conceptualisations appears to be the inclusion of a broader array of financial transfers in GGP, including the transfer of wealth and assets. Whereas the measures of wealth and assets are not comparable between the GGP and SHARE, measures of educational level, which is often used as a proxy for socioeconomic status, are. This provides the second hypothesis:

H2: The difference between SHARE and the GGP will be greatest among the highly educated.

The third hypothesis in the analysis examines the extent to which the reference period used in the question affects the response rate, and thus gives some indication of its relevance. For this it is possible to use SHARE data, as respondents were given different reference periods depending on whether it was the first or second time they had been interviewed. If it was the first time, then they were asked about the last 12 months. If it was their second interview, they were asked about the period since the last interview, which ranged between 18 and 36 months due to fieldwork windows varying between countries. A simple theory would state that the longer the time period, the more likely it is that an individual has made a transfer. However, as the previous section detailed, methodological literature has suggested that longer reference periods put greater emphasis on respondent recall and this can systematically bias the types of 
transfer that are recorded. It is therefore expected that longer reference periods are associated with fewer transfers being reported:

H3: The longer the reference period, the less likely it is that the respondent reported making a financial transfer.

The final issue that this paper examines is the level of measurement error stemming from asking parents compared to children. Definitively testing whether parents and children are reporting the same transfers is difficult given the lack of a sampling frame for parent-child relationships and problems of non-response on both nodes. Yet it is possible to examine the differences between individual donors and recipients, given that the GGP includes both within its sample for a wide age range. We can therefore examine the extent to which young persons' reporting of receiving financial transfers reflects the parents' reporting of giving financial transfers that is examined in the previous three hypotheses. To do this, respondents can be matched with other respondents who share similar characteristics regarding their parent/children, using their basic demographic information such as age, education, marital status, and number of children. Based on an assumption that transfer-giving is viewed positively and transfer-receiving is viewed negatively, it is anticipated that children will underreport receiving transfers and parents will over-report giving transfers (Schaeffer and Presser 2003). The fourth hypothesis in this analysis is therefore:

H4: The receipt of a transfer is less likely to be reported by the child node than the giving of a transfer is by the parental node.

Nevertheless, there are credible reasons for believing that the effect may be in the opposite direction. Parents could be concealing the dependence of their children and children may be keen to acknowledge the support their parents provide. Hypothesis 4 therefore seeks to test for this respondent effect and to establish whether it is evident with regard to intergenerational transfers. In answering these hypotheses this paper aims to provide a clearer picture of what existing measures of financial transfers are capturing and what they are not. In doing so it is possible to provide context to some of the research conducted with existing data and possible ways in which the data collection process itself could be improved. 


\section{Results}

\subsection{Prompts}

The first part of analysis aims to examine the differences in reported transfer behaviour between SHARE and the GGP and to consider the extent to which this might be driven by the wording of the questions. The data on transfer-giving by parents from SHARE and the GGP were made as comparable as possible by limiting the age range in both surveys to 50-79 years. In addition, the data for SHARE was taken from Wave 1 and Wave 2, but only interviews with new respondents were used so that the reference period was always one year, and therefore comparable to the GGP data. Both surveys had cross-sectional weights applied that ensured that each sample was representative of the population. Once this was completed the proportion of the population stating that they had made a financial transfer to a child was calculated and the results are presented in Figure 1.

\section{Figure 1: Intergenerational transfers in SHARE and the GGP}

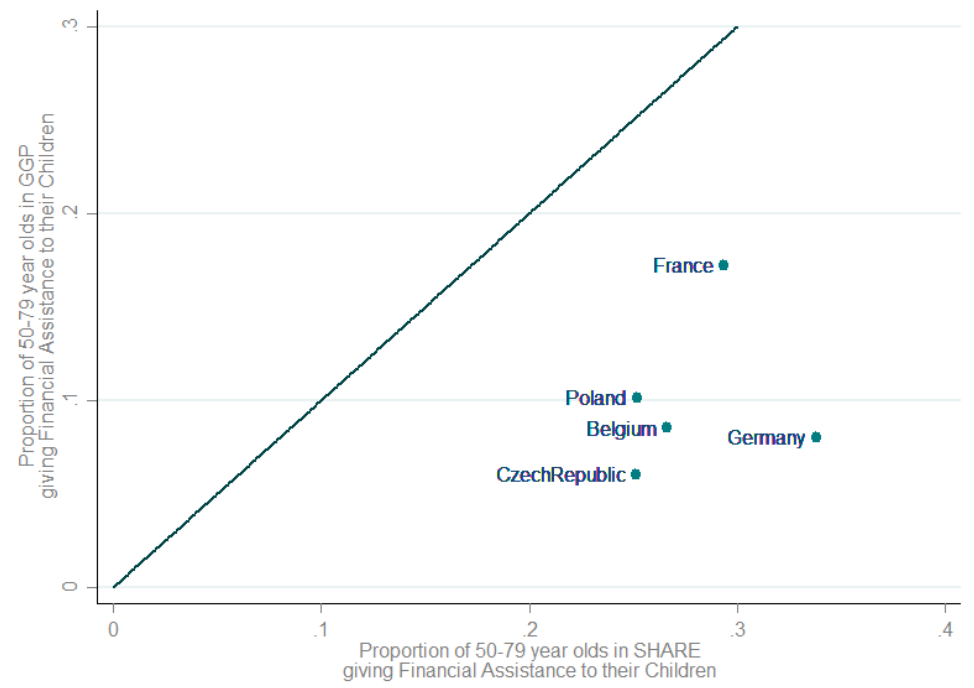

In this figure the black diagonal line represents parity between the two surveys and the positioning of all five countries below that line suggests that the estimate for the 
proportion of the population making a transfer in the last 12 months is considerably higher in SHARE than in the GGP. This may suggest that the wording in SHARE provides a more inclusive measure of transfers, but to rule out the effect of sample differences between the two surveys a Propensity Score Matching (PSM) analysis was undertaken. This analysis matches all those respondents from SHARE with their closest possible match in the GGP and compares whether they made a transfer or not. The matching between SHARE and GGP respondents was based upon their age, marital status, occupational status, number of children, educational level, gender, and country of residence. Table 1 shows the PSM results. The first line shows the difference between the two samples before they have been matched. Prior to matching the proportion of respondents making a financial transfer in SHARE was 18.8 percentage points higher than in the GGP. The difference rose slightly to 19.2 percentage points once the matching had been conducted. This suggests that the GGP question is recording far less transfer activity than the SHARE question.

\section{Table 1: Results of propensity score matching of respondents' transfer} behaviour

\begin{tabular}{lccccc}
\hline Sample & SHARE & GGP & Difference & S.E. & T-stat \\
\hline Unmatched & 0.2922 & 0.1041 & 0.1881 & 0.0049 & 38.27 \\
Matched & 0.2922 & 0.1006 & 0.1917 & 0.0060 & 31.83 \\
\hline
\end{tabular}

One observation is that the gap between the GGP and SHARE is smallest in France, where the translation of the initial question omitted the reference to "substantive value". It is therefore possible that respondents in the GGP omitted all transfers they did not feel to have been of substantive value, when they were actually only prompted to consider goods of substantive value in addition to other types of material transfers, such as money, regardless of their value. If the use of the term 'substantive' in the GGP is leading to omissions, then this is disconcerting, given that the term 'substantive' only refers to "goods" and is intended to limit the inclusion of goods to those that have value beyond emotional or sentimental.

It might be suspected that higher levels of transfers would be evident in the GGP, given that it included an explicit prompt for the transfer of property, land, and material goods of substantive value, and that this would lead to the biggest discrepancies between the two surveys being between the highly educated. If it is the case that the term 'substantive' is leading to omissions, then one might expect those of lower socioeconomic status to be less affected, as they would view a greater proportion of transfers as being of substantive value. If one assumes that "substantive" adds a degree of subjective interpretation to the GGP wording, it should be expected that those from 
lower socio-economic groups will report similar findings in the two surveys because they will view almost all transfers as having substantive value. However, those from higher socio-economic groups will omit some smaller transfers that do not affect their day-to-day lives or living conditions because they do not view them as 'substantive', despite being of the same monetary value as a transfer that a lower socio-economic group would classify as 'substantive'.

\section{Table 2: $\quad$ Probit model of transfer behaviour in GGP and SHARE by} educational level

\begin{tabular}{ll}
\hline & Model 1 \\
\hline GGP*Low Edu & 0 \\
SHARE*Low Edu & 0 \\
GGP*Med Edu & $()$. \\
& 0 \\
SHARE*Med Edu & $()$. \\
GGP*High Edu & $0.34 \quad * * *$ \\
& $(0.047)$ \\
SHARE*High Edu & 0 \\
Constant & $()$. \\
\hline & $0.295 \quad * * *$ \\
\hline N & $(0.055)$ \\
II & $-1.452 * * *$ \\
aic & $(0.040)$ \\
\hline
\end{tabular}

Note: Dependent variable is whether the respondent made a transfer in the last 12 months. Pooled sample of GGP and SHARE respondents. Reference category for educational level is "Low". Reference category for survey is "GGP".

Examining the educational differential in transfers across the two surveys to test the second hypothesis may therefore help further clarify the source of the difference between the two surveys. To make the comparison, a probit model was constructed which included the same independent variables as the PSM and a dummy variable indicating whether the respondent was from the SHARE sample or the GGP sample. To 
test the hypothesis, interaction effects were then included between the respondents' educational level and the sample they were from ${ }^{5}$. The results from the pooled model suggest that the difference between SHARE and the GGP is significantly higher for those in medium (ISCED '97: 3 and 4) and high (ISCED '97: 5 and 6) education categories. This suggests that the transfers that are included in the SHARE measure and excluded by the GGP measure are more likely to be reported among these groups.

\subsection{Reference period}

In addition to the wording in the existing instruments, there are also questions about the reference period for transfers that need to be considered. In the previous analysis only respondents' first interview in SHARE and GGP was used so that the reference period was always 12 months. However, in SHARE respondents' second interview the reference period was the time between interviews, which could range from around 18 to 40 months. This is a large difference in reference periods and raises questions about the comparability of responses between countries where fieldwork schedules differ. The variation in the reference period also allows us to examine its effect on the reporting of transfers. The degree of variation in these reference periods is evident from the histogram in Figure 2. The data is taken from 11 countries $^{6}$ that each have a slightly distinct fieldwork timetable. For example, the average reference period was 32 months in the Netherlands but just 21 months in Belgium.

\footnotetext{
${ }^{5}$ The estimated coefficients for these interaction effects are included in the full model, which is available on request.

${ }^{6}$ Austria, Germany, Sweden, Netherlands, Spain, Italy, France, Denmark, Greece, Switzerland, Belgium.
} 
Figure 2: Frequency distribution of 'months since last interview' for respondents at their second interview (SHARE, Wave 2$)(\mathrm{N}=\mathbf{1 8 , 6 2 3})$

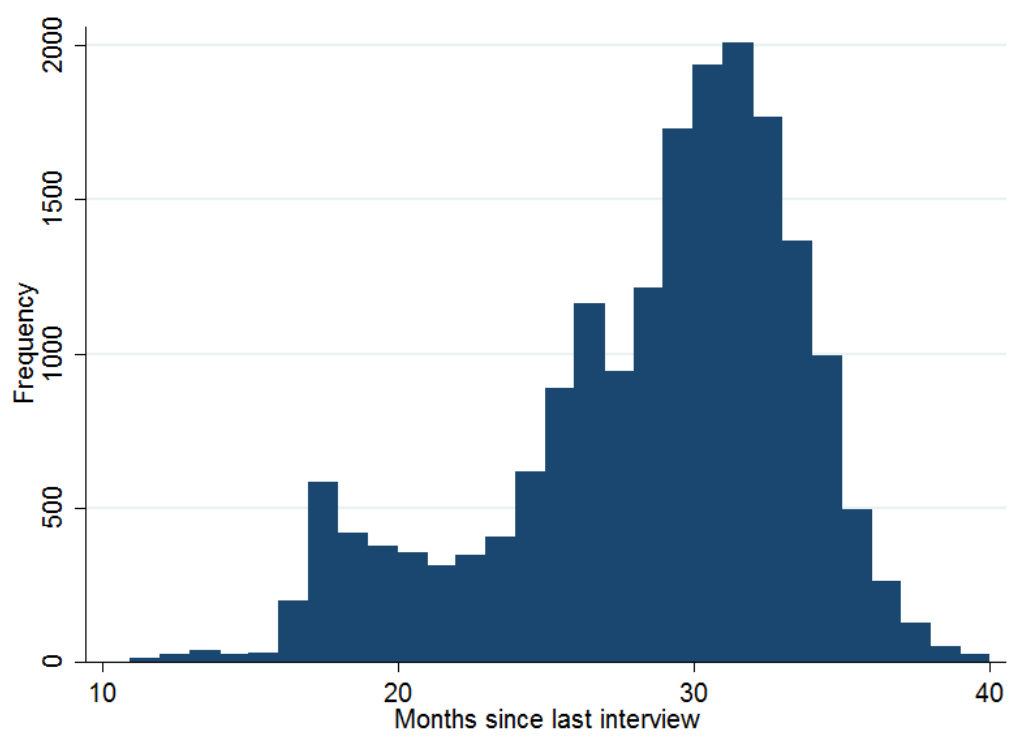

There is also variation within countries. In all the countries for which data is available, the range between the lowest and highest number of months between a Wave 1 interview and a Wave 2 interview is at least a year and in most cases between 14-16 months. Some respondents, therefore, have a reference period that is approximately $50 \%$ longer than other respondents from the same country. It lies outside of the scope of this paper to examine whether this variation is associated with any demographic variables. However, it is of interest to examine whether the variation is related to the recorded transfer behaviour. The 'common sense' logic suggests that the longer the reference period, the more likely that a transfer was made. Nevertheless, given existing research (Schwarz and Oyserman 2001), it is suspected that longer reference periods are in fact associated with less transfer behaviour being recorded. To examine this, a probit analysis was conducted that predicted whether the respondent would report a transfer. Age, education level, employment status, marital status, gender, number of children, and country of residence were used as controls, and the key independent variable was the length of the reference period. The square of the reference period was also included in order to account for non-linearity. The average marginal effects of this model are given in Figure 3. 
Figure 3: Predictive margins and $95 \%$ confidence intervals of reference period length (months) on the probability of recording having made a transfer (SHARE, Wave 2)

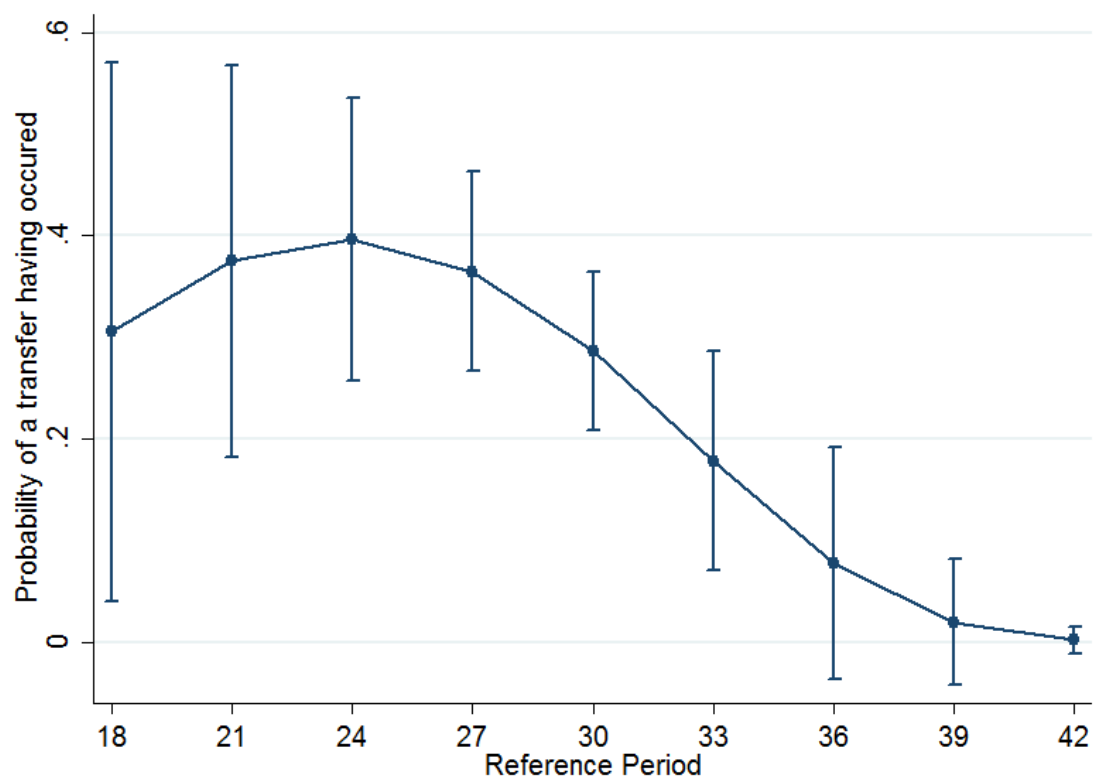

The results are very striking in that they reveal that the likelihood of recording that a transfer has been made does indeed decrease past a certain time point. It would appear from the analysis that once 24 months have passed the likelihood of recording a transfer actually starts to decrease. Respondents whose second interview was 24 months after the first one have a $39.6 \%$ chance of recording a transfer since Wave 1 . The probability of recording a transfer falls to just $7.8 \%$ for a respondent who was interviewed at 36 months. Even at 30 months, the probability of recording a transfer has fallen by $23 \%$ from its peak at 24 months. This is of interest, given that 44\% of the SHARE Wave 2 sample had their Wave 2 interview at least 30 months after their first wave interview. This suggests that respondents start to forget that they made certain transfers past a certain point or choose to omit them under the assumption that reference to a long period in time means that the concept is limited to only substantial transfers. 
To examine this further, a second model was run with the same covariates as the previous model but with 'total amount transferred' as the dependent variable and restricted only to those who had stated they had made at least one transfer. The results suggest that predicted total amount transferred mirrors the probability of making a transfer by first decreasing and then increasing. This suggests that the transfers that are forgotten are smaller. However, the coefficient for the reference period is only significant at a $90 \%$ confidence level and the quadratic term is not significant. This means that, overall, our analysis regarding the effect on transfer size is inconclusive.

There are several factors that could lead to the observation of higher transfers for later reference periods. For example, as with the analysis in Figure 3, the results could be driven by the extent to which the timing of the second interview is also associated with other socio-economic indicators and the national team conducting the fieldwork. Nevertheless, as with the first two hypotheses, the results appear to suggest that the response to questions about financial transfers is highly dependent upon the manner in which the question is asked. The main driver behind the broad confidence intervals observed in both Figures 3 and 4 is, however, the sample size. To provide more conclusive evidence on the effect of reference period on recorded transfers it would be necessary to carry out systematic tests which ensure that the reference period varied sufficiently and that respondents were allocated to a broad spectrum of reference periods in order to more closely observe the variation in responses. Researchers could then explore the potential conceptual differences in reported transfer behaviour. 
Figure 4: Average marginal effects of reference period length (months) on the predicted total amount transferred by those who made at least one transfer (SHARE, Wave 2)

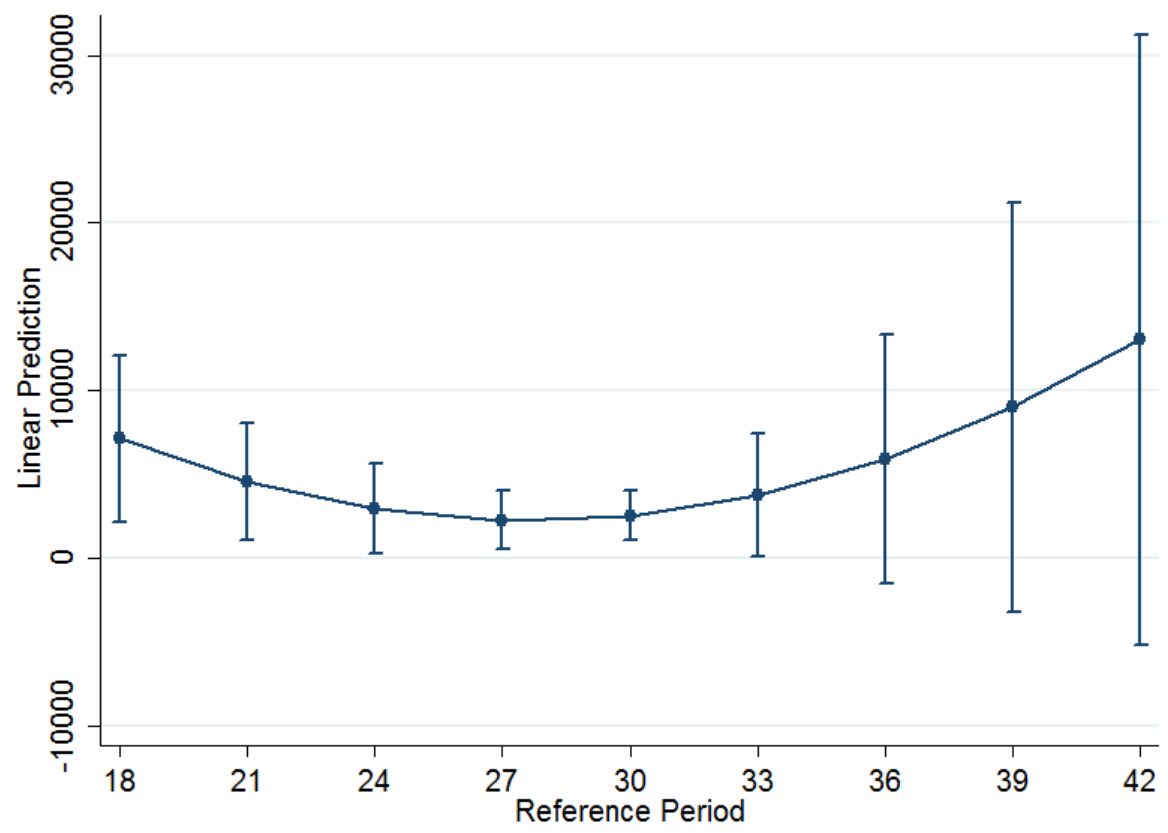

\subsection{Anchors}

Having established that what is asked and when it is asked is important, the fourth hypothesis considers whether who is asked is important. To assess whether the identity of the anchor influences reporting, the full sample from the GGP data is used, given that it is representative of the population aged 18-79 and thus includes both recipients and donors of financial transfers. By exploiting this fact, the analysis can compare the responses of recipients of transfers with the responses of those who have made transfers. To conduct the analysis, the sample was duplicated to reflect that each individual is a potential giver and a potential recipient of an intergenerational financial transfer. There are, however, exceptions to this. Firstly, those whose parents had died or who were co-resident with them were removed as potential recipients from the sample. Moreover, those who had no non-coresident children were removed from the sample as 
potential givers of financial transfers. Variables were then recoded to reflect the dyadic nature of the new unit of analysis. For example, a variable was created which indicated the educational level of the parental node. For those in the sample who were recipients, this was the educational level of their parents, and for those who were potential givers of financial transfers, this was their own educational level. This was conducted for parent's age, children's age, parent's educational level, financial transfer behaviour, and the number of siblings the child node has. ${ }^{7}$ Once these variables were created it was possible to perform PSM analysis to ascertain the extent to which the likelihood of a transfer being recorded was different if the respondent was the parent or the child. The results of this analysis are given in Table 3 .

Table 3: $\quad$ Results of propensity score matching of respondents' transfer behaviour for parental and child nodes

\begin{tabular}{lccccc}
\hline Sample & Parent & Child & Difference & S.E. & T-stat \\
\hline Unmatched & 0.13027 & 0.14860 & -0.01833 & 0.00340 & -5.39 \\
Matched & 0.13318 & 0.14860 & -0.01542 & 0.00344 & -4.48 \\
\hline
\end{tabular}

The results suggest that before matching, parental nodes were actually 1.8 percentage points less likely to record a transfer. Once matching had been conducted this fell to 1.5 percentage points but still suggests that children are $11.5 \%$ $((0.14860 / 0.13318) * 100=1.115)$ more likely to report having received a transfer than their parents are to report having given one. This finding must, however, be kept in perspective, as while the difference is significant it is also quite small.

\section{Discussion}

This paper set out to examine the extent to which the conceptualization of intergenerational transfers is comparable between two cross-national European surveys. The findings suggest that the instruments are different and that this has consequences for the use of the instruments as measures of the conceptualization of transfers within the substantive literature. Furthermore, they suggest that measures of intergenerational transfers are highly dependent on methodological design decisions. The confirmation of

\footnotetext{
${ }^{7}$ It is, however, important to note that the financial transfer variable for children also includes inheritance received from parents. This should have a limited effect on the results, given that the sample is limited to individuals who have at least one parent still alive and will thus only include individuals who have had one parent die in the last year. As a sensitivity analysis, only those with both parents still alive were analysed and the results remained the same.
} 
the first hypothesis suggested that SHARE's question wording recorded more financial transfers than the GGP, and this is believed to be derived from the prompt in terms of the euro amount in the SHARE question and the use of the term "substantive" in the GGP question. This suggests that including prompts that refer to explicit amounts of money may lead to a more inclusive recording of the transfer behaviour of respondents, as they are encouraged to think of payments that they may otherwise have dismissed as irrelevant or simply forgotten. Similarly, the use of subjective judgments such as the term 'substantive' may not be limited to the part of the clause to which they grammatically belong but could affect the respondent's broader understanding of the concept.

This interpretation is supported by the confirmation of the second hypothesis. The analysis showed that the difference between SHARE and the GGP was highest among those from higher education levels. This suggests that the payments that were not recorded in the GGP came from those with greater assets. Whilst it cannot be fully tested, given the lack of comparable financial data between the two surveys, this systematic difference in reported transfers would appear to indicate that including a financial amount as a prompt within the question wording encourages those with higher levels of assets to include lower transfer amounts. It would have been possible to test this theory more thoroughly if the data from the GGP had contained transfer amounts; however this was not the case.

More broadly, these conclusions suggest that the respondents' recall of financial transfers is 'soft' in that it is greatly affected by the wording of the question. This belief is also strongly supported by the finding from the third hypothesis. Here, the results support the hypothesis in that the reference period appears to be negatively correlated with the reported likelihood of making at least one transfer. However, it does seem to have some positive correlation with the reported total amount transferred. This may suggest that a long reference period leads to respondents omitting small transfers and only including large transfers. This once again suggests that the type of transfer that is included is very dependent upon the context in which the question is asked.

This finding, however, is dependent upon the association with other socioeconomic indicators. It could be that those who are of lower socio-economic status are harder to contact during fieldwork and therefore have longer reference periods. This could mean that they are given longer reference periods but are generally less likely to provide financial support. Yet we do not believe this to be the case, given that it is inconsistent with the positive relationship between average transfer size and the length of the reference period. If the timing between Waves 1 and 2 is not associated with the socio-economic indicators, then differential transfer behaviour could be attributable to different reference periods and not other factors. For example, comparative analysis of transfers has been common in the intergenerational transfer literature. Wave 2 of 
SHARE should be used with considerable caution for such comparative analysis, given the dependence of transfer behaviour on the fieldwork particularities in each country, which could lead to systematic bias in the measures of financial transfers. More generally, it raises the question of what types of transfer are excluded by both the GGP and SHARE Wave 1 by having a reference period as long as one year. If survey instruments are to accurately capture transfer behaviour, a greater understanding of the relationship between reference period and transfer reporting is needed.

In addition to these limitations in the measurement of financial transfers, there is also the issue of ego-centric methods in transfer research and the anchoring of responses to either the parent or the child. The concern was that in asking only the parents about financial transfers, a bias was introduced due to the fact that parents may be more likely to record a transfer than children. From an examination of parents' and children's responses that were matched using the GGP data, the opposite proved to be the case, potentially suggesting that either parents are reluctant to report transfers or children are more willing to report them. Whilst the difference is small, it suggests that researchers should consider both the parental perspective and the child perspective in examining intergenerational transfer behaviour. It would, however, be wrong to suggest that the analysis of this matter is conclusive, given that it was conducted using only the measure of transfers available in the GGP. This could be problematic if children perceive transfers to be of importance whilst parents see them as irrelevant or too small to remember. This problem may therefore be circumvented by including a prompt for a specific financial amount, as in SHARE, for both the receiving and giving of financial transfers.

This paper has illustrated that instruments measuring intergenerational financial transfers capture a very specific conceptualisation of transfer activity. The proportion of individuals recording any transfer behaviour appears to be very dependent on the way the question is worded, the reference period to which it refers, and who is being asked the question. The solution to this is not to recommend a singular way of asking about such financial transfers. Instead, a variety of measures should be encouraged across existing survey infrastructures that address utilizing different techniques, prompts, and sampling frames so that transfer behaviour can be better understood. The difference between the instruments in the GGP and SHARE is subtle but the outcomes are very different and from this divergence insights can be gathered, and, as this paper has shown, these insights may occasionally be counter to conventional thinking. Given that the vast majority of literature on intergenerational financial transfers in Europe is based on the SHARE data, methodological dependency is an important issue that needs to be addressed.

The instruments used within the GGP and SHARE are not directly comparable, given the subtle differences in their methodology. In addition to this, even within 
SHARE the measurement of transfers varies in its conceptualization, given the varying reference periods applied in the longitudinal element of the survey. Correcting for these differences is not possible without a far clearer understanding of what is captured by various instruments. Such an understanding needs to come from structured methodological research into the instruments employed, including field experiments. This is also a precondition for any future advances in our theoretical understanding of intergenerational transfers and the role they might play in various sociological processes. Until such research is completed, the existing literature remains on unstable ground and opportunities to advance our understanding of intergenerational transfers will be hamstrung.

\section{Acknowledgements}

This paper uses data from SHARE Waves 1 and 2 (DOIs: 10.6103/SHARE.w1.260, 10.6103/SHARE.w2.260), see Börsch-Supan et al. (2013) for methodological details.*

The SHARE data collection has been primarily funded by the European Commission through FP5 (QLK6-CT-2001-00360), FP6 (SHARE-I3: RII-CT-2006062193, COMPARE: CIT5-CT-2005-028857, SHARELIFE: CIT4-CT-2006-028812) and FP7 (SHARE-PREP: N²11909, SHARE-LEAP: N²27822, SHARE M4: $\mathrm{N}^{\circ}$ 261982). Additional funding from the German Ministry of Education and Research, the U.S. National Institute on Aging (U01_AG09740-13S2, P01_AG005842, P01_AG08291, P30_AG12815, R21_AG025169, Y1-AG-4553-01, IAG_BSR06-11, OGHA_04-064) and from various national funding sources is gratefully acknowledged (see www.share-project.org). 


\section{References}

Albertini, M. and Kohli, M. (2012). The Generational Contract in the Family: An Analysis of Transfer Regimes in Europe. European Sociological Review 29(4): 828-840. doi:10.1093/esr/jcs061.

Albertini, M. and Radl, J. (2012). Intergenerational transfers and social class: Intervivos transfers as means of status Reproduction? Acta Sociologica 55(2): 107123. doi:10.1177/0001699311431596.

Albertini, M., Kohli, M., and Vogel, C. (2007). Intergenerational transfers of time and money in European Families: Common Patterns different regimes? Journal for European Social Policy 12(4): 319-334. doi:10.1177/0958928707081068.

Alcser, K.H., Benson, G., Börsch-Supan, A., Brugiavini, A., Christelis, D., Croda, E., and Das, M. (2005). The Survey of Health, Aging, and Retirement in EuropeMethodology. Mannheim: Mannheim Research Institute for the Economics of Aging (MEA).

Attias-Donfut, C., Ogg, J., and Wolff, F. (2005). European Patterns of Intergenerational Financial and Time Transfers. European Journal of Ageing 2(3): 161-173. doi:10.1007/s10433-005-0008-7.

Brandt, M. and Deindl, C. (2013). Intergenerational Transfers to Adult Children: Do Social Policies Matter? Journal of Marriage and Family 75(1): 235-231. doi:10.1111/j.1741-3737.2012.01028.x.

Brandt, M., Haberkern, K., and Szydlik, M. (2009). Intergenerational Help and Care in Europe. European Sociological Review 25(5): 585-601. doi:10.1093/esr/jcn076.

Cox, D. and Jimenez, E. (1992). Social Security and Private Transfers in Developing Countries: The Case of Peru. World Bank Economic Review 6(1): 155-169. doi:10.1093/wber/6.1.155.

Emery, T. (2013). Intergenerational transfers and European families: Does the number of siblings matter? Demographic Research 29(10): 247-274. doi:10.4054/Dem Res.2013.29.10.

Fokkema, T., Kveder, A., Hiekel, N., and Liefbroer, A.C. (2015). Generations and Gender Programme Wave 1 Data Collection: An Overview and Assessment of Sampling and Fieldwork Methods, Weighting Procedures and Cross-Sectional Representativeness. Demographic Research: Forthcoming. 
Hagestad, G.O. (2006). Transfers between grandparents and grandchildren: The importance of taking a three-generation perspective. Zeitschrift für Familienforschung - Journal of Family Research 18(3): 315-332.

Handcock, M.S. and Gile, K.J. (2010). Modeling social networks from sampled data. The Annals of Applied Statistics 4(1): 5-25. doi:10.1214/08-AOAS221.

Igou, E., Bless, H., and Schwarz, N. (2002). Making sense of standardized survey questions: The influence of reference periods and their repetition. Communication Monographs 69(2): 179-187. doi:10.1080/714041712.

Kalmijn, M. and Liefbroer, A.C. (2010). Nonresponse of Secondary Respondents in Multi-Actor Surveys: Determinants, Consequences, and Possible Remedies. Journal of Family Issues 32(6): 735-766. doi:10.1177/0192513X10390184.

Kohli, M. (1999). Private and Public Transfers between Generations: Linking the Family and the State. European Societies 1(1): 81-104.

Lennartson, C. (2010). Need and support: determinants of intra-familial financial transfers in Sweden. International Journal of Social Welfare 20(1): 66-74. doi:10.1111/j.1468-2397.2009.00715.x.

Leopold, T. and Raab, M. (2011). Short Term Reciprocity in Late Parent-Child Relationships. Journal of Marriage and Family 73(1): 105-119. doi:10.1111/j.1741-3737.2010.00792.x.

Leopold, T. and Schneider, T. (2010). Family Events and the Timing of Intergenerational Transfers. SOEP paper No. 327. doi:10.2139/ssrn.1722513.

Mandemakers, J.J. and Dykstra, P.A. (2008). Discrepancies in parent's and adult child's reports of support and contact. Journal of Marriage and Family 70(2): 495-506. doi:10.1111/j.1741-3737.2008.00496.x.

Marsden, P.V. (2011). Survey methods for network data. The SAGE handbook of social network analysis: $370-388$.

McDaniel, S.A. (1997). Intergenerational Transfers, Social Solidarity, and Social Policy: Unanswered Questions and Policy Challenges. Canadian Public Policy 23(Special Joint Issue: Aging): 1-21. doi:10.2307/3551538.

Mudrazija, S. (2014). The Balance of Intergenerational Family Transfers: A Life-Cycle Perspective. European Journal of Ageing 11(3): 249-259. doi:10.1007/s10433013-0302-8. 
Rooney, P., Steinberg, K., and Schervish, P.G. (2004). Methodology is destiny: The effect of survey prompts on reported levels of giving and volunteering. Nonprofit and Voluntary Sector Quarterly 33(4): 628-654. doi:10.1177/0899 764004269312.

Schaeffer, N.C. and Presser, S. (2003). The science of asking questions. Annual Review of Sociology 29: 65-88. doi:10.1146/annurev.soc.29.110702.110112.

Schenk, N., Dykstra, P., and Maas, I. (2010). The role of European welfare states in intergenerational money transfers: a micro-level perspective. Ageing \& Society 30(8): 1315-1342. doi:10.1017/S0144686X10000401.

Schwarz, N. and Oyserman, D. (2001). Asking questions about behavior: Cognition, communication, and questionnaire construction. American Journal of Evaluation 22(2): 127-160. doi:10.1177/109821400102200202.

Szydlik, M. (2008). Intergenerational Solidarity and Conflict. Journal of Comparative Family Studies 39(1): 97-114. 


\section{Appendix}

Table A1: Survey fieldwork methodology and questions in field languages

\begin{tabular}{|c|c|c|c|c|c|c|c|c|c|c|}
\hline & \multicolumn{2}{|c|}{ Belgium } & \multicolumn{2}{|c|}{ Germany } & \multicolumn{2}{|c|}{ France } & \multicolumn{2}{|c|}{ Poland } & \multicolumn{2}{|c|}{ Czech Republic } \\
\hline & SHARE & GGP & SHARE & GGP & SHARE & GGP & SHARE & GGP & SHARE & GGP \\
\hline Sampling Method & $\begin{array}{l}\text { PPS \& } \\
\text { SRS }\end{array}$ & SRS & $\begin{array}{l}\text { PPS \& } \\
\text { SRS }\end{array}$ & $\begin{array}{c}\text { PPS \& } \\
\text { SRS }\end{array}$ & $\begin{array}{l}\text { PPS \& } \\
\text { SRS }\end{array}$ & $\begin{array}{l}\text { PPS \& } \\
\text { SRS }\end{array}$ & NIA & SRS & NIA & $\begin{array}{l}\text { PPS \& } \\
\text { SRS }\end{array}$ \\
\hline Year & 2005 & 2008 & 2004 & 2005 & 2004 & 2005 & 2007 & 2010 & 2007 & 2005 \\
\hline Response Rate & $39.2 \%$ & $41.8 \%$ & $63.4 \%$ & $55.4 \%$ & $81.0 \%$ & $64.7 \%$ & N/A & $33.3 \%$ & N/A & $49.1 \%$ \\
\hline $\begin{array}{l}\text { Institutionalised } \\
\text { Population Included }\end{array}$ & No & No & No & No & No & No & No & No & No & Yes \\
\hline Survey Mode & CAPI & CAPI & CAPI & CAPI & CAPI & CAPI & CAPI & PAPI & CAPI & PAPI \\
\hline Number of Respondents & 2,532 & 7,171 & 2,002 & 10,017 & 2,110 & 10,079 & 1,771 & 19,987 & 1,943 & 11.293 \\
\hline
\end{tabular}

Note: PPS = Probability Proportional to Size Method; SRS = Simple Random Sampling; CAPI = Computer Assisted Personal Interview; PAPI = Paper and Pencil Interview; N/A = Not Available.

\section{SHARE}

\section{English}

Now please think of [the time since the last interview, that is since /the last twelve months $][$ \{month year previous interview\}/\{empty\}]. Not counting any shared housing or shared food, have you [or/or/or/or/\{empty $\} /\{$ empty $\}]$ [your/your/your/your/\{empty\}/\{empty\}] [husband/wife/partner/partner/\{empty\}/\{empty\}] given any financial or material gift or support to any person inside or outside this household amounting to [\{empty\}] [\{local currency\}] or more?

IWER: BY FINANCIAL GIFT WE MEAN GIVING MONEY, OR COVERING SPECIFIC TYPES OF COSTS SUCH AS THOSE FOR MEDICAL CARE OR INSURANCE, SCHOOLING, DOWN PAYMENT FOR A HOME. DO NOT INCLUDE LOANS OR DONATIONS TO CHARITIES. 


\section{Belgium}

Denkt $\mathrm{u}$ aan [de periode sinds het laatste interview, dat wil zeggen sinds/de afgelopen twaalf maanden][\{maand en jaar van vorig interview\}/\{empty\}]. Gedeelde huisvesting of voedsel niet meegerekend, hebt u [of/of/of/of/\{empty\}/\{empty\}] [uw/uw/uw/uw/\{empty\}/\{empty\}] [man/vrouw/partner/partner/\{empty\}/\{empty\}] financiële of materiële hulp aan iemand (in uw huishouden of daarbuiten) gegeven voor een bedrag van $[\{$ empty $\}][\{$ Euro $\}]$ of hoger?

IWER:MET FINANCIËLE HULP WORDT BEDOELD GELD, HULP BIJ HET BETALEN VAN SPECIFIEKE KOSTEN ZOALS VOOR MEDISCHE ZORG OF EEN VERZEKERING, OPLEIDING, EEN AANBETALING VOOR EEN HUIS.REKEN LENINGEN OF DONATIES AAN GOEDE DOELEN NIET MEE

\section{Czech Republic}

[V době od posledního interview, to jest od/V posledních dvanácti měsících][\{měsíc a rok předchozího interview\}/\{empty\}], když nebudete brát v úvahu stravu a ubytování, podporoval/a jste Vy [nebo/nebo/nebo/nebo/\{empty\}/\{empty\}] [Váš/Vaše/Váš/Vaše/\{empty\}/\{empty\}]

[manžel/manželka/partner/partnerka/\{empty\}/\{empty\}] v tomto období nějakou osobu uvnitř Vaší domácnosti nebo mimo ni penězi nebo věcnými dary v hodnotě $[\{2.500\}]$ $[\{K \check{Y}\}]$ a více?

TAZATEL:VEDLE FINANČNÍ PODPORY V HOTOVOSTI JE NUTNÉ JAKO PENĚŽNÍ DARY CHÁPAT I PŘEVZETÍ URČITÝCH NÁKLADU゚, NAPŘ. NA ZDRAVOTNÍ PÉČI NEBO POJIŠTĚNÍ, NA VZDĚLÁNÍ, NA POŘÍZENÍ BYTU NEBO DOMU. ÚVĚRY A DARY CHARITATIVNÍM ORGANIZACÍM SE NEPOČÍTAJÍ.

\section{France}

Veuillez maintenant penser [au temps écoulé depuis notre dernier entretien, c'est-à-dire depuis/aux douze derniers mois][mois année interview prédédente/\{empty\}]. Sans tenir compte du partage d'un logement ou de repas, vous est-il arrivé à vous [ou à/ou à/ou à/ou à/\{empty $\} /\{$ empty\}] [votre/votre/votre/votre/\{empty\}/\{empty\}] [ mari/ femme/compagnon/compagne/\{empty\}/\{empty\}] de faire un don ou d'apporter un soutien financier ou matériel à une personne, faisant partie ou non de votre ménage, 
d'un montant de [\{250\}] [EUROS] ou plus?

\section{Germany}

Denken Sie jetzt bitte an [die Zeit seit dem letzten Interview, also seit/die letzten zwölf Monate][\{Monat und Jahre des letzten Interviews\}/\{empty\}]. Wenn Sie freie Kost und Unterkunft unberücksichtigt lassen, haben Sie [oder/oder/oder/oder/\{empty\}/\{empty\}] [Ihr/Ihre/Ihr/Ihre/\{empty\}/\{empty\}] [Mann/Frau/Partner/Partnerin/\{empty\}/\{empty\}] in dieser Zeit eine Person innerhalb oder außerhalb ihres Haushalts mit Geld- oder Sachgeschenken im Wert von [\{250\}] [Euro] oder mehr unterstützt?

IWER:NEBEN ZUWENDUNGEN IN BAR SIND UNTER GELDGESCHENKEN AUCH DIE ÜBERNAHME VON BESTIMMTEN KOSTEN, Z.B. FÜR MEDIZINISCHE VERSORGUNG, VERSICHERUNGEN, AUSBILDUNG ODER ANZAHLUNGEN FÜR WOHNEIGENTUM ZU VERSTEHEN. KREDITE ODER SPENDEN AN GEMEINNÜTZIGE ORGANISATIONEN NICHT ZÄHLEN

\section{Poland}

Proszę teraz pomyśleć o [okresie od czasu ostatniego badania /okresie ostatnich dwunastu miesięcy][(\{month year previous interview $\}) /\{$ empty $\}]$. | Nie licząc jakichkolwiek wydatków związanych ze wspólnym mieszkaniem lub jedzeniem, czy [udzielał Pan/udzielała Pani] [lub/lub/lub/lub/\{empty\}/\{empty\}] [Pani/Pana/Pani/Pana/\{empty\}/\{empty\}]

[mąż/żona/partner/partnerka/\{empty\}/\{empty\}] jakiejkolwiek finansowej lub materialnej pomocy lub wsparcia o wartości [\{200\}] [\{empty\}] lub więcej jakiejkolwiek osobie w tym gospodarstwie domowym lub poza nim?

ANKIETER:PRZEZ POMOC FINANSOWA ROZUMIEMY DAWANIE PIENIĘDZY LUB POKRYWANIE OKREŚLONYCH RODZAJÓW KOSZTÓW, JAK KOSZTY OPIEKI MEDYCZNEJ LUB UBEZPIECZENIA, NAUKI, SPŁATY DOMU. PROSZE NIE UWZGLĘDNIAĆ POŻYCZEK I DARÓW DLA ORGANIZACJI CHARYTATYWNYCH. 


\section{GGP Country-Specific Wording}

\section{English}

During the last 12 months, have you or your partner/spouse received for one time, occasionally, or regularly money, assets, or goods of substantive value from a person outside the household? Please think also about land and property or inheritance that was transferred to you or your partner/spouse during this time.

\section{Belgian (French)}

$\mathrm{Au}$ cours des 12 derniers mois, vous-même ou votre conjoint/compagnon (conjointe/compagne) avez-vous reçu de façon exceptionnelle, occasionnelle ou régulière de l'argent, des valeurs ou des biens de valeur significative, donnés par une personne extérieure à votre ménage ? N'oubliez pas les terrains, propriétés ou héritages que vous (ou votre conjoint/compagnon (conjointe/compagne)) avez reçu au cours de cette période.

\section{Czech Republic}

Dostal/a jste Vy nebo Váš/e partner/ka během posledních 12 měsíců jednou, př́leţitostně, nebo vícekrát peníze, aktiva nebo předměty větší hodnoty od osoby mimo Vaši domácnost? Zahrňte, prosím, i pozemky a majetek nebo dědictví, které byly na Vás nebo Vašeho partnera (Vaši partnerku) v této době převedeny.

\section{Germany}

Haben Sie oder Ihr(e) (Ehe-)Partner/in in den letzten zwölf Monaten einmal, gelegentlich oder regelmäßig Geld, Vermögen oder sonstige Wertgegenstände von einer Person außerhalb des Haushalts erhalten? Denken Sie dabei bitte auch an Grundstücke oder Erbschaften, die Sie oder Ihr(e) (Ehe )Partner/in in dieser Zeit erhalten haben. 


\section{France}

Au cours des douze derniers mois, vous-même ou votre conjoint avez-vous reçu de façon exceptionnelle, occasionnelle ou régulière de l'argent, des valeurs ou des biens, donnés par une personne extérieure à votre ménage? N'oubliez pas les terrains, propriétés ou héritages que vous (ou votre conjoint) avez reçus au cours de cette période.

\section{Poland}

Czy w ciągu ostatnich 12 miesięcy Pan(i) lub Pana(i) współmałżonek(ka)/ partner(ka) OTRZYMALIŚCIE jednorazowo, sporadycznie lub regularnie pieniądze, środki trwałe lub przedmioty dużej wartości od osoby nie będącej członkiem gospodarstwa domowego? Proszę wziąć także pod uwagę ziemię i majątek lub spadki przekazane Panu(i) lub współmałżonkowi(ce)/ partnerowi(ce) w tym czasie. 